\title{
РОЛЬ ПОЛІМОРФІЗМУ ГЕНІВ ЛЕПТИНУ ТА РЕЦЕПТОРА ДО ЛЕПТИНУ У РЕАЛІЗАЦІЇ МЕТАБОЛІЧНИХ ЕФЕКТІВ ОМЕГА-З ПОЛІНЕНАСИЧЕНИХ ЖИРНИХ КИСЛОТ У ХВОРИХ НА ЦУКРОВИЙ ДІАБЕТ 2 ТИПУ СХІДНОУКРАÏНСЬКОÏ ПОПУЛЯЦІї
}

\author{
Красова Н. С. ${ }^{1}$, Караченцев Ю. І. ${ }^{1,2}$, Горшунська М. Ю. ${ }^{2}$, Колеснікова А. О. ${ }^{1}$, \\ Лещенко Ж. А. ${ }^{1}$, Гладких О. I. ${ }^{1}$, Воропай T. I. ${ }^{1}$, Романова I. П. ${ }^{1}$, Полторак В. В. ${ }^{1}$ \\ ${ }^{1}$ ДУ «Інститут проблем ендокринної патологї̈ ім. В. Я. Данилевського НАМН України», \\ м. Харків, Україна; \\ ${ }^{2}$ Харківська медична академія післядипломної освіти, м. Харків, Украӥна \\ nkrasova@ukr.net
}

За останніми даними Міжнародної Діабетичної Федерації натепер більше 463 млн. дорослих осіб у всьому світі мають діагноз цукрового діабету (ЦД), більшу частину яких (близько $90 \%$ від діабетичного загалу) складае ЦД 2 типу [1]. В свою чергу, серед паціентів з ЦД 2 типу близько $80 \%$ мають надлишкову масу тіла або ожиріння [2]. Доведено, що жирові клітини (адипоцити) виконують ряд важливих функцій. Серед них регуляція енергетичного обміну, чутливості тканин до інсуліну, імунної відповіді та контроль стану кровоносних судин, що має місце завдяки продукції широкого ряду біологічно активних речовин, адипокінів [3]. Вочевидь, що за ожиріння та ЦД 2 типу функціонування цієї складної регуляторної системи суттєво змінюеться. Крім того, генетичні, епігенетичні, а також екологічні чинники надають свого внеску до розвитку патологічного процесу, пов’язаного з ожирінням, інсулінорезистентністю (IP) та прогресуванням предіабету [4-5]. Останнім часом інтенсивно накопичуються дані відносно того, що конкретні однонуклеотидні поліморфіз-

* Роботу виконано в рамках договору про сумісну наукову діяльність між ДУ «Інститут проблем ендокринної патології ім. В. Я. Данилевського НАМН України», Харківською медичною академією післядипломної освіти та Національним інститутом охорони громадського здоров’я та екології (м. Білтховен, Нідерланди) (узгодження б/н RIVM від 18.10.2008 р.) «Адипоцитокіни та патерн чутливості до інсуліну у хворих на цукровий діабет 2 типу, що лікувалися n-3 поліненасиченими жирними кислотами» та в рамках фундаментальної НДР (2019-2021 рр.) ДУ «Інститут проблем ендокринної патології ім. В. Я. Данилевського НАМН України» «Визначення функціональної ролі релевантних щодо розвитку цукрового діабету 2 типу однонуклеотидних поліморфізмів генів-кандидатів в реалізації гормонально-метаболічних ефектів фармакологічних чинників» (№ держреестрації 0119U002135).

Установою, що фінансує дослідження, е НАМН України.

Автори гарантують колективну відповідальність за все, що опубліковано в статті.

Автори гарантують відсутність конфлікту інтересів та власної фінансової зацікавленості.

Рукопис надійшов до редакції 03.08.2021. 
ми (ОНП) генів адипокінів людини здатні впливати на функціонально-метаболічні параметри, задіяні в розвитку ожиріння, ЦД 2 типу та серцево-судинних захворювань [6-8]. Гормон жирової тканини лептин $€$ важливим регулятором енергетичних процесів, який реалізує свою активність через специфічний трансмембранний рецептор, присутній у мембранах широкого кола клітин різноманітних тканин, тому триває активний пошук функціонально значущих ОНП як власно гена лептину $(L E P)$, так i гена його рецептору $(L E P R)$ в різних популяціях [8-12]. 3 іншого боку, з'являються результати, які верифікують омега-3 поліненасичені жирні кислоти (ПНЖК) в якості важливих регуляторів експресії генів, а саме, природних лігандів для ряду факторів транскрипції [13]. Суперечливі ре- зультати клінічних досліджень стосовно едективності (в першу чергу, відносно зниження ризику серцево-судинних захворювань) збагачення дієти ПНЖК пов'язують як 3 жирнокислотним складом базової національної дієти, так і 3 генетичними особливостями популяції [14-15]. Дотепер відсутня вичерпна інформація щодо генетичної детермінації ефрективності терапії, яка спрямована на корекцію енергетичного дисбалансу, за умов ожиріння та ЦД 2 типу у мешканців України.

Мета. Оцінити вплив поліморфних варіантів генів лептину LEP 2548G>A (rs7799039) та рецептора до лептину $L E P R$ $223 G>A$ (rs1137101) на терапевтичну ефективність омега-3 поліненасичених жирних кислот у хворих на цукровий діабет 2 типу східноукраїнської популяції.

\section{МАТЕРІАЛИ ТА МЕТОДИ}

Обстежено 61 хворого на ЦД 2 типу 3 підтвердженим згідно встановлених вимог діагнозом (ж/ч: 27/34, клініка ДУ ІПЕП iм. В. Я. Данилевського НАМНУ) віком $53,35 \pm 1,38$ років 3 тривалістю захворювання 5,33 \pm 0,67 років, рівнем глікозильованого гемоглобіну $\left(\mathrm{HbA}_{1 \mathrm{c}}\right)$ 7,74 \pm 0,19\%, 3 індексом маси тіла $33,28 \pm 0,89 \kappa 5 / \mathrm{m}^{2}$, зі співвідношенням обсягу талії до обсягу стегон 0,99 \pm 0,01, з наявністю ішемічної хвороби серця у 34 випадках, гіпертонічної хвороби - у 49, їх сполучення - у 33. У 59 осіб спостерігалися мікроангіопатії (у 43 - полінейропатії, у 49 - ретино-, у 1 - кардіоміо- та у 10 - недропатія). Антидіабетична терапія обстежених включала пероральні цукрознижуючі препарати (сульфонілсечовину та/або метформін) без лікарських засобів, що спрямовані на ліпідний обмін, а також додатково щоденно протягом 3 місяців препарат омега-3 ПНЖК (460 мг ейкозапентаєнової кислоти $($ ЕПК) + 380 мг докозагексаєнової кислоти (ДГК)). Контрольну групу склала 21 практично здорова особа відповідного віку та статі. Від обстежених було отримано інформовану згоду на проведення клініко-біохімічних та генетичних досліджень згідно протоколам медичної етики ДУ ІПЕП. Усіх пацієнтів опитували щодо повної історії хвороби, яка включала вік, стать, рід занять, тривалість діабету, режим та тривалість лікування, наявність будь-якої супутньої хвороби, історію хірургічних втручань, особисту історію куріння / зловживання алкоголем / лікарськими засобами, дієтичні звички та сімейний анамнез ЦД.

Окрім загальноприйнятого лабораторного обстеження у вихідному стані та після курсу лікування в еритроцитах вимірювали вміст відновленого/окисненого глутатіону колориметрично, вільні жирні кислоти (ВЖК) сироватки крові - за використанням набору Wako Diagnostics (США). Наступні показники плазми/сироватки крові визначали імуноферментно: інсулін (DRG, Німеччина), лептин, програнулін, васпін, оментин-1 (Biovendor, Чеська Республіка), адипонектин загальний та високомолекулярний (ALPCO Diagnostics, США), високочутливий C-реактивний білок (вч-СРБ) (Roche Diagnostics, Швейцарія), резистин, матриксна металопротеїназа-9 (EC 3.4.24.35), остеопротегерин (RayBiotech, США), ретинол-зв'язуючий протеїн 4, фретуін-A (ICL, CШA), інтерлейкін-6, фрактор некрозу пухлин а (R\&D Systems, Велика Британія).

Інсулінорезистентність (IP) характеризували за індексом HOMA-IR, IP жирової 
тканини - за індексом HOMA-IR/адипонектин та Adipo-IR [16].

ДНК з лейкоцитів екстрагували за використанням іонообмінної смоли Chelex-100. Генотипування обстежених проводили за методом полімеразної ланцюгової реакції та поліморфізму довжин рестриктних фрагментів з використанням відповідних праймерів (LEP 2548G > A: прямий: tcccatgagaactattcttcttttg; зворотній: atatggetccetttgcccgacc; LEPR 223G > A: прямий: acctctggttcccсаaаaag; обернений: tcatcattttagtgcataacttaccc) та ендонуклеаз (HhaI і $M s p I$ відповідно). Продукти рестрикції проаналізували за допомогою електрофорезу в 2 \% агарозному гелі. Як маркер молекулярної маси використали ДНК pUC19, гідролізовану ендонуклеазою MspI (MBI Fermentas, Литва).

Нормальність розподілу змінних визначили за допомогою критерію КолмогороваСмірнова. Застосовували непарний та парний двобічний $t$-критерій Стьюдента, критерій Манна-Уітні та критерій $x^{2}$ (хі-квадрат). Перевірка нульових гіпотез проведена на рівні значущості $\mathrm{P} \leq 0,05$. За умов нормального розподілу даних, вони наведені у вигляді середніх арифметичних значень із статистичною похибкою, окремі дані наведено у вигляді медіани та 25-ї і 75-ї процентилі.

\section{РЕЗУЛЬТАТИ ТА ЇХ ОБГОВОРЕННЯ}

Відносно контрольних осіб обстежені хворі на ЦД 2 типу характеризувалися статистично значущою надлишковою масою тіла, абдомінальним типом розподілу жиру, резистентністю до інсуліну, гіпоадипонектинемією, підвищенням у циркуляції лептину, тригліцеридів, вч-СРБ, ІЛ-6, остеопротегерину, ретинол-зв'язуючого протеїну-4 та фетуіну-А, зниженням рівнів внутрішньоклітинних антиоксидантів (табл.).

Після стаціонарного лікування з подальшим амбулаторним курсом омега-3 ПНЖК у обстежених паціентів, стратифікованих за поліморфізмом гена $L E P 2548 G>A$, було визначено деяку нормалізацію показника $\mathrm{HbA}_{1 c}$, який характеризуе довгостроковий глікемічний контроль, лише серед носіїв рецесивного $A A$-генотипу $(6,66 \% \pm 0,41 \%$ проти 7,79 \% \pm 0,43 \% до лікування, $0,05<\mathrm{P}<0,1)$ на тлі виразного зниження базальної глікемії в усіх групах (див. табл.).

В той же час хворі на ЦД 2 типу з $G$-алелем за ОНП $L E P$ 2548G > A продемонстрували суттеве зниження індекcy HOMA-IR (GA: 4,51 ум. од. $\pm 0,36$ ум. од. проти 8,18 ум. од. $\pm 1,11$ ум. од., $\mathrm{P}<0,002$; $G G: 3,81$ ум. од. $\pm 0,69$ ум. од. проти $8,42$ ум. од. $\pm 1,29$ ум. од., $\mathrm{P}<0,002)$. Крім того, в групі з гетерозиготним генотипом спостерігалося зниження співвідношення HOMA-IR/адипонектин $(2,89$ ум. од. \pm 0,89 ум. од. проти 0,86 ум. од. $\pm 0,12$ ум. од., $\mathrm{P}<0,05)$, яке супроводжувалося підви- щенням рівнів загального адипонектину в циркуляції $(7,12 \mathrm{мг/л} \pm 0,84 \mathrm{мг/л} \mathrm{проти}$ 4,97 мг/л \pm 0,51 мг/л, $\mathrm{P}<0,05)$, що свідчить про нормалізацію гормональної фрннкції білої жирової тканини під впливом омега-3 ПНЖК переважно у носіїв поліморфного варіанту GA.

Після аналізу обстежених хворих на ЦД 2 типу залежно від генотипу $L E P R 223 G>A$ було визначено окремі статеві розбіжності реалізації терапевтичного впливу омега-3 ПНЖК. Так, тільки у чоловіків-носіїв $G G$-генотипу було виявлено суттєве зниження індексу Adipo-IR, пов'язаного з жировою тканиною (66,1 ум. од. $(40,1 ; 99,8)$ ум. од. проти 148,1 ум. од. $(75,9 ; 155,9)$ ум. од., $\mathrm{P}<0,001)$, а також рівнів $\mathrm{HbA}_{1 \mathrm{c}}(6,95 \% \pm$ $0,51 \%$ проти $8,26 \% \pm 0,47 \%, \mathrm{P}<0,05)$, а у $G G$-гомозиготних жінок було визначено зменшення рівнів проатерогенної ММП9 в циркуляції (2107,0 мкг/л \pm 319,3 мкг/л проти 3903,0 мкг/л \pm 806,6 мкг/л, $\mathrm{P}<0,05)$. Крім того, в аналізі за рецесивною моделлю $(A A$ проти $G G+G A)$ було виявлено суттеву нормалізуючу відповідь індексу НОМАIR / адипонектин у носіїв $A A$-генотипу обох статей після курсу омега-3 ПНЖК $(A A: 1,70$ ум. од. $(0,67 ; 2,34)$ ум. од. проти 0,57 ум. од. $(0,33 ; 0,97)$ ум. од., $\mathrm{P}<0,02$; $G G+G A: 1,62$ ум. од. $(1,38 ; 2,68)$ ум. од. проти 1,03 ум. од. $(0,59 ; 1,45)$ ум. од., $\mathrm{P}>0,05$, відповідно. Це узгоджуеться 3 даними, отриманими для монголоїдних популяцій 
Біохімічні показники у хворих на цукровий діабет 2 типу до та після курсу лікування з додаванням поліненасичених жирних кислот

\begin{tabular}{|c|c|c|c|}
\hline \multirow{2}{*}{ Показник } & \multicolumn{2}{|c|}{ Хворі на ЦД 2 типу } & \multirow{2}{*}{$\begin{array}{c}\text { Контрольна } \\
\text { група }\end{array}$} \\
\hline & До лікування & Після лікування & \\
\hline Глюкоза крові натще, ммоль/л & $9,06 \pm 0,41^{\#}$ & $6,53 \pm 0,37 * \#$ & $5,52 \pm 0,49$ \\
\hline $\mathrm{NGSP} / \mathrm{HbA}_{1 \mathrm{c}}, \%$ & $7,74 \pm 0,19^{\#}$ & $7,13 \pm 0,22^{\#}$ & $5,4 \pm 0,10$ \\
\hline Інсулін натще, пмоль/л & $145,04 \pm 13,14^{\#}$ & $108,21 \pm 9,21^{* \#}$ & $85,21 \pm 8,00$ \\
\hline HOMA-IR індекс, ум. од. & $8,96 \pm 0,89^{\#}$ & $4,69 \pm 0,35^{* \#}$ & $3,06 \pm 0,28$ \\
\hline HOMA-IR/адипонектин, ум. од. & $2,60 \pm 0,65^{\#}$ & $0,91 \pm 0,10^{* \#}$ & $0,48 \pm 0,09$ \\
\hline Adipo-IR, ум. од. & $120,65 \pm 11,03^{\#}$ & $92,82 \pm 10,70^{* \#}$ & $59,25 \pm 7,14$ \\
\hline Тригліцериди, ммоль/л & $3,15 \pm 0,53^{\#}$ & $2,71 \pm 0,25^{\#}$ & $1,56 \pm 0,20$ \\
\hline Вільні жирні кислоти, ммоль/л & $0,89 \pm 0,07^{\#}$ & $0,84 \pm 0,05^{\#}$ & $0,70 \pm 0,06$ \\
\hline ХС-ЛПВЩ, ммоль/л & $1,00 \pm 0,04^{\#}$ & $1,11 \pm 0,06^{* \#}$ & $1,51 \pm 0,09$ \\
\hline ХС-ЛПНЩ, ммоль/л & $3,24 \pm 0,17$ & $3,67 \pm 0,21$ & $3,84 \pm 0,30$ \\
\hline Лептин, мкг/л & $70,75 \pm 8,31^{\#}$ & $67,59 \pm 7,31^{\#}$ & $11,52 \pm 1,87$ \\
\hline Інтерлейкін-6, нг/л & $10,57 \pm 1,54^{\#}$ & $7,96 \pm 0,72^{\#}$ & $3,37 \pm 0,83$ \\
\hline $\begin{array}{c}\text { Високочутливий } \\
\text { C-реактивний білок, мг/л }\end{array}$ & $7,81 \pm 2,53^{\#}$ & $4,65 \pm 0,77$ & $3,36 \pm 0,91$ \\
\hline $\begin{array}{c}\text { Ретинол-зв'язуючий } \\
\text { протеїн-4, мг/л }\end{array}$ & $33,60 \pm 1,53^{\#}$ & $33,21 \pm 1,70^{\#}$ & $23,01 \pm 1,82$ \\
\hline Загальний адипонектин, мг/л & $5,03 \pm 0,37^{\#}$ & $6,38 \pm 0,60^{* \#}$ & $11,80 \pm 1,45$ \\
\hline $\begin{array}{c}\text { Адипонектин високої } \\
\text { молекулярної ваги, мг/л }\end{array}$ & $2,39 \pm 0,29^{\#}$ & $2,84 \pm 0,34^{\#}$ & $6,80 \pm 0,91$ \\
\hline Остеопротегерин, пг/мл & $522,67 \pm 44,17^{\#}$ & $362,66 \pm 28,21^{*}$ & $312,56 \pm 24,78$ \\
\hline Фетуін-А, мкг/мл & $127,00 \pm 4,54^{\#}$ & $124,29 \pm 3,68^{\#}$ & $103,11 \pm 4,44$ \\
\hline $\begin{array}{c}\text { Відновлений глутатіон, } \\
\text { мкмоль/ммоль Нb } \\
\end{array}$ & $27,93 \pm 2,27^{\#}$ & $33,94 \pm 2,52^{* \#}$ & $50,52 \pm 4,44$ \\
\hline
\end{tabular}

Примітки:

Ум. од. - умовні одиниці,

ХС-ЛПВЩ - холестерин ліпопротеїнів високої щільності,

ХС-ЛПНЩ - холестерин ліпопротеїнів низької щільності,

HOMA-IR - Homeostasis Model Assessment Insulin Resistance,

NGSP/HbA $1 \mathrm{c}$ - National Glycohemoglobin Standartization Program/HbA 1 ;

* - $\mathrm{P}<0,05$ відносно групи до лікування;

\# - $\mathrm{P}<0,05$ відносно контрольної групи.

щодо зв'язку $G$-алеля за $L E P R 223 G>A$ з ризиком розвитку ЦД 2 типу [12]. Слід відзначити, що досліджені поліморфізми не впливали на рівні лептину в циркуляції.

Останнім часом накопичуеться значна кількість результатів, в першу чергу, завдяки дослідженням in vitro, які верифікують омега-3 ПНЖК в якості важливих регуляторів експресії генів, а саме, природних лігандів рецепторів, активованих проліфератором пероксисом (peroxisome pro- 
IP за умов ожиріння завдяки утриманню нормального рівня експресії переносника глюкози GLUT4 у м'язах та жировій тканині, а також через регуляцію активності та експресії глюкозо-6-фоссратази печінки, що знижуе печінкову секрецію глюкози та посилюе синтез глікогену в скелетних м'язах [13]. В той же час конкретні механізми впливу ПНЖК за різного генетичного та епігенетичного підгрунтя потребують подальших поглиблених досліджень. Таким чином, отримані результати дозволяють стверджувати, що вивчені поліморфізми генів адипокінової ланки (лептину та рецептору до лептину) мають вплив на реалізацію терапевтичної гормонально-метаболічної ефективності препарату омега-3 ПНЖК за умов 3-місячного введення у пацієнтів з ЦД 2 типу та надлишковою масою тіла/ожирінням східноукраїнської популяції.

\section{ВИСНОВКИ}

1. Визначено, що хворі на цукровий діабет 2 типу східноукраїнської популяції, носії домінантного алеля $G$ за однонуклеотидним поліморфізмом $2548 G>A$ гена лептину, демонструють більшу ефективність омега-3 поліненасичених жирних кислот відносно зниження загальної інсулінорезистентності та інсулінорезистентності жирової тканини.

2. Виявлено асоціацію рецесивного генотипу $(A A)$ за поліморфізмом $223 G>A$ гена рецептора лептину з більшою терапев- тичною ефективністю омега-3 поліненасичених жирних кислот відносно зменшення інсулінорезистентності жирової тканини.

3. Дані щодо поліморфного варіанту гена LEP (rs1137101) та/або LEPR (rs1137101) можуть бути використані в межах фармакогенетики як підгрунтя для персоналізованої профрілактики та терапії з прогнозованим ефектом фармакологічного втручання.

\section{ЛITЕРАТУРА \\ (REFERENCES)}

1. International Diabetes Federation. Diabetes Atlas. $9^{\text {th }}$ Ed, Brussels, 2019: 176 p. available at: http://www.idf.org.

2. Rowley WR, Bezold C, Arikan Y, et al. Popul Health Manag 2017;20: 6-12.

3. Giralt M, Cereijo R, Villarroya F. Handb Exp Pharmacol 2016;233: 265-282.

4. Sheikh A, Nasrulla A, Haq S, et al. Cureus 2017;9(7): e1435. https://doi.org/10.7759/cureus.1435.

5. Laxhuber KS, Morrison MJ, Chure G, et al. PLoS One 2020;15(5): e0226453. https://doi.org/10.1371/journal. pone. 0226453 .

6. Li C, Yang Y, Liu X, et al. Diabetol Metab Syndr 2020; 12(1): 97. https://doi.org/10.1186/s13098-020-00604-5.

7. Kasim NB, Huri HZ, Vethakkan SR, et al. Biomark Med 2016;10(4): 403-415.

8. Zayani N, Omezzine A, Boumaiza I, et al. J Clin Lab Anal 2017;31(6): e22148. https://doi.org/10.1002/jcla.22148.

9. Manriquez V, Aviles J, Salazar L, et al. Mol Diagn Ther 2018;22(1): 101-113.
10. Wang H, Wang C, Han W, et al. Rev Soc Bras Med Trop 2020;53: e20190388. https://doi.org/10.1590/0037-86820388-2019.

11. Aljanabi MA, Alfaqih MA, Khanfar M, et al. Biomed Rep 2021;14(5): 44. https://doi.org/10.3892/br.2021.1420.

12. Li Y-Y, Wang H, Yang X-X, et al. Oncotarget 2017;8(37): 61927-61934.

13. O'Connell TD, Mason RP, Budoff MJ, et al. Eur Heart $J$ (Suppl) 2020;22(Suppl. J): J3-J20.

14. Vanden Heuvel JP. Prog Mol Biol Transl Sci 2012;108: 75-112.

15. Vallee Marcotte B, Cormier H, Rudkowska I, et al. $J$ Pers Med 2017;7(4): E15.

16. Adams-Huet B, Devaraj S, Siegel D, Jialal I. Metab Syndr Relat Disord 2014;12(10): 503-507.

17. Bosviel R, Joumard-Cubizolles L, Chinetti-Gbaguidi G, et al. Free Radic Biol Med 2017;103: 146-154. 


\title{
РОЛЬ ПОЛІМОРФІЗМУ ГЕНІВ ЛЕПТИНУ \\ ТА РЕЦЕПТОРА ДО ЛЕПТИНУ У РЕАЛІЗАЦІІ МЕТАБОЛІЧНИХ ЕФЕКТІВ ОМЕГА-З ПОЛІНЕНАСИЧЕНИХ ЖИРНИХ КИСЛОТ \\ У ХВОРИХ НА ЦУКРОВИЙ ДІАБЕТ 2 ТИПУ СХІДНОУКРАЇНСЬКОÏ ПОПУЛЯЦІї
}

\author{
Красова Н. С. ${ }^{1}$, Караченцев Ю. І., ${ }^{1,2}$, Горшунська М. Ю. ${ }^{2}$, \\ Колеснікова А. О. ${ }^{1}$, Лещенко Ж. А. ${ }^{1}$, Гладких О. I. ${ }^{1}$, Воропай T. I. ${ }^{1}$, \\ Романова І. П. ${ }^{1}$, Полторак В. В.' \\ ${ }^{1}$ ДУ “Інститут проблем ендокринної патологї̈ ім. В. Я. Данилевського НАМН України», \\ м. Харків, Україна; \\ ${ }^{2}$ Харківська медична академія післядипломної освіти, \\ м. Харків, Україна \\ nkrasova@ukr.net
}

Відомо, що однонуклеотидні поліморфізми (ОНП) в генах адипокінів здатні впливати як на розвиток патологічних станів, пов'язаних з ожирінням, так і на ефективність застосованої фармакотерапії.

Мета. Оцінити вплив поліморфних варіантів генів лептину $L E P 2548 G>A$ (rs7799039) та рецептора до лептину $L E P R 223 G>A(r s 1137101)$ на терапевтичну ефективність омега-3 поліненасичених жирних кислот у хворих на цукровий діабет 2 типу східноукраїнської популяції.

Матеріали та методи. 61 хворий на цукровий діабет (ЦД) 2 типу (ч/ж: 34/27, вік 53,4 $\pm 1,4$ років, тривалість захворювання 5,3 \pm 0,7 років, глікемія 9,1 \pm 0,4 ммоль/л; $\left.\mathrm{HbA}_{1 c} 7,7 \pm 0,2 \%\right)$ з надлишковою масою тіла або ожирінням (індекс маси тіла $33,3 \pm 0,9 \mathrm{\kappa r} / \mathrm{m}^{2}$ ) отримував додатково до стандартної пероральної цукрознижуючої терапії (сульфонілсечовина та/або метформін) щоденно протягом 3 місяців препарат омега-3 поліненасичених жирних кислот (ПНЖК) (460 мг ейкозапентаенової кислоти + 380 мг докозагексаєнової кислоти). Контрольну групу складав 21 суб'єкт. Клініко-біохімічні параметри оцінювали до та після курсу лікування. Генотипування за ОНП $L E P 2548 G>A$ та $L E P R$ $223 G>A$ проводили за допомогою методу полімеразної ланцюгової реакції з використанням відповідних праймерів та ендонуклеаз (HhaI і MspI).

Результати. Визначено, що хворі на ЦД 2 типу носії домінантного алеля $G$ за ОНП $2548 G>A$ гена лептину демонструють більшу ефективність омега-3 ПНЖК відносно зниження загальної інсулінорезистентності та інсулінорезистентності жирової тканини. Виявлено асоціацію рецесивного генотипу $(A A)$ за поліморфізмом $223 G>A$ гена рецептора лептину з більшою ефективністю омега-3 ПНЖК відносно зменшення інсулінорезистентності жирової тканини.

Висновки. Вивчені поліморфізми генів адипокінової ланки мають вплив на реалізацію терапевтичної гормонально-метаболічної ефективності препарату омега-3 ПНЖК за умов 3-місячного введення у пацієнтів з ЦД 2 типу та надлишковою масою тіла/ожирінням східноукраїнської популяції. Дані щодо поліморфного варіанту гена $L E P$ та/або $L E P R$ можуть бути використані в межах фармакогенетики як підірунтя для персоналізованої профрілактики та терапії з прогнозованим ефектом фрармакологічного втручання.

Ключ юв і слова: цукровий діабет 2 типу, ген лептину, ген рецептора до лептину, поліморфізм, поліненасичені жирні кислоти.

\section{THE ROLE OF LEPTIN AND LEPTIN RECEPTOR GENE POLYMORPHISM IN THE OMEGA-3 POLYUNSATURATED FATTY ACIDS METABOLIC EFFECT REALIZATION IN TYPE 2 DIABETIC PATIENTS OF THE EAST UKRAINIAN POPULATION}

\author{
N. Krasova ${ }^{1}$, Yu. Karachentsev ${ }^{1,2}$, M. Gorshunska ${ }^{2}$, \\ A. Kolesnikova ${ }^{1}$, Zh. Leshchenko', A. Gladkih ${ }^{1}$, T. Voropai ${ }^{1}$, \\ I. Romanova ${ }^{1}$, V. Poltorak ${ }^{1}$ \\ ${ }^{1}$ SI «V. Danilevsky Institute for Endocrine Pathology Problems of the NAMS of Ukraine», \\ Kharkiv, Ukraine, \\ ${ }^{2}$ Kharkiv Postgraduate Medical Academy, \\ Kharkiv, Ukraine; \\ nkrasova@ukr.net
}

It is known that single nucleotide polymorphisms (SNPs) in the adipokine genes can affect both the development of pathological conditions associated with obesity and the effectiveness of pharmacotherapy.

Aim. To evaluate the impact of polymorphic variants for leptin gene $L E P 2548 G>A$ (rs7799039) and leptin receptor gene $L E P R 223 G>A$ (rs1137101) on the omega-3 polyunsaturated fatty acids therapeutic efficacy realization in patients with type 2 diabetes mellitus of the East Ukrainian population.

Materials and methods. A total of 61 patients with type 2 diabetes mellitus (DM) (m/f 34/27; age $53.4 \pm 1.4 \mathrm{yrs}$, diabetes duration $5.3 \pm 0.7 \mathrm{yrs}$; fasting blood glucose $9.1 \pm 0.4 \mathrm{mmol} / \mathrm{l}$; HbA1c $7.7 \pm 0.2 \%$ ) overweight or obese (body mass index $33.3 \pm 0.9 \mathrm{~kg} / \mathrm{m}^{2}$ ) were received in addition to standard oral hypoglycemic 
therapy (sulfonylurea and/or metformin) daily for 3 months the omega-3 polyunsaturated fatty acids (PUFA) (460 mg eicosapentaenoic acid $+380 \mathrm{mg}$ docosahexaenoic acid). The control group consisted of 21 subjects. Clinical and biochemical parameters were assessed before and after the treatment. Genotyping by SNP LEP $2548 G>A$ and $L E P R 223 G>A$ was performed using the polymerase chain reaction method with appropriate primers and endonucleases (HhaI and $M s p I)$.

Results. It was determined that type 2 DM patients carriers of the dominant G-allele (SNP LEP 2548G $>A$ ) show greater effectiveness of omega-3 PUFA in reducing of total insulin resistance and adipose tissue insulin resistance. The association of recessive genotype $(A A)$ by SNP $L E P R 223 G>A$ with greater efficiency of omega-3 PUFA in reducing adipose tissue insulin resistance was revealed.

Conclusions. The studied polymorphisms of the adipokine-associated genes have an impact on the implementation of therapeutic hormonal and metabolic efficacy of omega-3 PUFA under 3-month administration in patients with type $2 \mathrm{DM}$ and overweight/obesity of the East Ukrainian population. Data on polymorphic variants of the LEP and/or LEPR gene can be used within pharmacogenetics as a basis for personalized prophylaxis and therapy with a predicted effect of the pharmacological intervention.

Key words: type 2 diabetes mellitus, leptin gene, leptin receptor gene, polymorphism, polyunsaturated fatty acids. 